candidates will be examined in Pathology, i.e., the laws of epidemics, of contagion and infection, influence of hereditary disposition, \&c. ; in Chemistry, under the heads of I, air; 2, water; 3 , gaseous poisons ; 4 , principal deodorising and disinfecting agents; and in Medical Jurisprudence under the divisions of Hygiene and Forensic Medicine. This course has been evidently selected with great care; and appears well calculated to test the qualifcations of the candidates. The medical men who successfully pass it and obtain the diploma, ought certainly to be able to assist in establishing on a scientific basis the laws relating to the public health.

One very sericus omission we observe in the list of subjects to be examined in, and it is one we would have least expected, viz., the Microscope and Spectroscope. It is perfectly astonishing to find the number of well-educated men in the medical profession who are unable to understand the ordinary manipulation of an ordinary nuicroscope, or of a spectroscope in connection with the microscope. The medical men who pass this examination will, we believe, take rank at once as medical experts-but fancy one qualified to act as a medical expert and yet not knowing how to manage an achromatic condenser!

At present this movement of the Dublin University can but be regarded as an experiment, but it is an experiment in the right direction, and one that has been, and we hope for years will be, conducted inder the watchful eye of a most able physician, who thoroughly understands the subject of medical education, and who, throughout his whole life, has laboured to elevate the profession that he adorns.

\section{PRIMITIVE CULTURE*}

II.

$\mathrm{T}$ HE chapters on mythology, which naturally follow those on language, form an admirable summary of the history of myth from its vigorous infancy in the earlier ages of human thought through the various stages of growth and maturity onwards to second childhood, death by ossification of the heart, and final post-mortem existence through millenniums of disembowelled mummydom. Myth, in fact, is as ubiquitous, as multiform, as language. $\mathrm{Nay}$, it is perhaps more ubiquitous, more multiform. The spaniel, who fawns on his master or flies at a beggar, who bays at the moon or cowers from the thunder, has evidently framed to himself some simple dog-theory in connection with certain phenomena, which is closely analogous to, if it be not absolutely identical with, a rudimentary myth. It is, indeed, probably not too much to say that wherever a phenomenon is stated or explained, whether with or without the intervention of language, there exists a myth, though a higher knowledge than that which creates the myth is always requisite in order to recognise its mythic character. The Ptolemaic system of astronomy, for instance, has been long ago conclusively demonstrated to be a myth, although a myth belonging to an advanced stage of culture, and a thousand and a thousand others are everywhere around us only waiting for the extension of knowledge to effect the metamorphosis requisite for their recognition. It is evident that if

* "Primitive Culture : Researches into the Development of Mythology, Philosophy, Keligion, Art, and Custom." By Edward B. Tylor, author of (London: Murray, $x 87 \mathrm{I}$.) this theory of myth be even approximately correct, the statement or explanation of any phenomenon in language is in effect merely the creation of another phenomenon out of which myth may be evolved ad infinitum; in short, that myth is essentially the outcome of the complex action, reaction, interaction, and counteraction of human thought on the one hand, and the sensible phenomena of the universe, including those of language, on the other. The sensible phenomena of the universe may thus not inaptly be regarded from the standpoint of Democritus or Lucretius as continually throwing off films or likenesses of thernselves, which films or likenesses, once seized and appropriated by language, become additional phenomena, with a vitality, so to speak, and reproductive power of their own. On the other hand, if, in accordance with the spirit of Scandinavian philosophy, we regard philosophy itself, art, poetry, science, morality, and religion-all the products of human thought-as a single living organism, we may then consider myth as the former substance of the organism, the physical atoms which have been gradually eliminated and replaced in the process of growth and development. $\mathrm{Or}$, not to complicate matters by the introduction of evolution,--civilised knowledge, as a whole, may be likened to an old canoe, of which no plank nor nail is the same as when she started on her first voyage, and myth to the old timbers and metal which once formed a part of her, but have now been some lost, some metamorphosed into wholly different shapes, some utilised again in the construction of other vessels. We can thus understand how every department of thought has absorbed and assimilated more or less of myth,- - how myth has absorbed and assimilated more or less of every product of the human intellect. It is, in fact, the nonappreciation of the true place of myth in human knowledge, which has led so many earlier students of mythology astray. One school looked on all mythology as crystallised poetry; another as indurated chronicle; a third as frozen philosophy; a fourth as petrified religion, and so forth ;each school doing something towards really making mythology what it believed mythology to be, and all, as a net result, extracting from one of the most vitally-interesting investigations a mere caput mortuum of doublydistilled platitude, and quintessential commonplace. So long as "mythology" meant simply an acquaintance from without with the Greek and Roman Pantheon, such a result was, perhaps, inevitable. Unfortunately the doctrines of these schools are not even yet by any means universally recognised as being themselves mythic; and many of them are still to be found reproduced in contemporary works of no inconsiderable learning, to supply future students with illustrations of Mr. Tylor's theory of survival. It must be admitted, too, that even the late brilliant achievements of more scientific inquirers still leave a vast field untouched for classification and comparison. Nor is this task an easy one. A myth is always the statement or explanation of a phenomenon, and myths may thus be classified according to the phenomena to which they refer; but first of all "to catch your myth," and then to determine the phenomenon to which it refers, are feats, for the most part, beyond the skill of ordinary students. An amusing instance of these difficulties is afforded by Mr. Tylor himself. "No legend," he observes, "no allegory, no nursery rhyme, is safe from the her- 
meneutics of a thorough-going mythologic theorist. Should he, for instance, demand as his property the nursery 'Song of Sixpence,' his claim would be easily established: obviously the four-and-twenty blackbirds are the four-and-twenty hours, and the pie that holds them is the underlying earth, covered with the over-arching sky; how true a touch of nature is is that when the pie is opened-that is, when day breaks, the birds begin to sing; the King is the Sun, and his counting out his money is pouring out the sunshine, the golden shower of Danae; the Queen is the Moon, and her transparent honey the moonlight; the Maid is the 'rosy-fingered' Lawn, who rises before the Sun, her master, and hangs out the clouds, his clothes, across the sky; the particular blackbird, who so tragically ends the tale by snipping off her nose, is the hour of sunrise. The time-honoured rhyme really wants but one thing to prove it a Sun-myth, that one thing being a proof by some argument more valid than analogy." This is exquisitely ingenious ; but what if the rhyme should turn out to be, after all, only a quite genuine nursery riddle, of the type which Mr. Tylor has so admirably illustrated elsewhere? An archetypal clock, presented as a haute nouveauté to some Edward III. or Richard II, would satisfy all the conditions of the enigma. The large circular face would represent the pie;-the four-and-twenty hours duly figured thereon, in accordance with the liberal notions of archaic horology, would correspond to the four-and-twenty blackbirds; the strilking, possibly with chimes, to the song of the birds; the king in his counting-house, counting out his money, would felicitously symbolise the hour-hand counting out the time, which is money, in majestic solitude, unaccompanied as yet by any fussy revolutionary minute-hand; the queen in the pantry, eating bread and honey, would typify the stealthy activity of the fine wheel-teeth of steel arid brass; the maid in the garden, hanging out the clothes, would appropriately allegorise the wooden drum on which the weights were suspended by lines, at a distance from the works; while the magpie, which seems a preferable heading to "black-bird" who snaps off the maid's nose, would probably be none other than the ingenious mechanist who wound up the instrument, and, having done so, removed the key from the nozzle of the drum. Whatever may be thought of this interpretation, it seems exceedingly probable that the rhyme is really a riddle, and, indeed, many other unintelligible jingles are most likely referable to the same category. One of them, if a riddle, does also unquestionably enunciate a sun-myth. In the immortal Jack and Jill who went up a hill to fetch a pail of water, we may clearly recognise the sun and moon under an enigmatic, not to say riddleiculous exterior, and after satisfying ourselves as to their identity, we may further admire the curious felicity with which the difference of sex between Hêlios and Selênêetymologically identical with the difference between leôs, a lion, and leaina, a lioness-is indicated in the English ditty. To return, however, from the precincts of the nursery, Prof. Max Muller, with a natural bias in the direction of his own brilliant researches, seems to ascribe the origin of myth somewhat too exclusively to the influence of language, just as in his interpretation of myth he appears to pay a rather too marked attention to the DawnGoddess to do full justice to the claims of other less seductive divinities. The Professor himself, however, will probably be among the first to recognise the value of Mr. Tylor's distinction between material and verbal myth, and to acquiesce in the classification which considers the former as primary, the latter as secondary in the order of evolution.

In his account of eclipse-myths, Mr. Tylor quotes sundry remarks of Mr. Samuel Davies eighty years ago with regard to the struggle between ecclesiastical authority and science in India. "The learned Pundits," says Mr. Davies, "reject the ridiculous belief of the common Brahmuns, that eclipses are occasioned by the intervention of the monster Rahoo, with many other particulars equally unscientific and absurd. But as this belief is founded on explicit and positive declarations contained in the 'Vedus' and 'Pooranus,' the divine authority of whose writings no devout Hindoo can dispute, the astronomers have some of them cautiously explained such passages in those writings as disagree with the principles of their own science; and where reconciliation was impossible, have apologised as well as they could for propositions necessarily established in the practice of it by observing that certain things, as stated in other Shastrus, might have been so formerly and may be so still, but for astronomical purposes astronomical rules must be followed." It is, perhaps, not a mere accidental coincidence that in $I 760$, a few years before this was written, the following "Declaratio" appeared at the end of the third volume of the Jesuit edition of Newton's works, published at Geneva :- "Newtonus in hoc tertio libro telluris motæ hypothesem assumit. Autoris propositiones aliter explicari non poterant, nisi eâdem quoque factâ hypothesi. Hinc alienam coacti sumus gerere personam. Cœterum latis a summis pontificibus contra telluris motum decretis, nos obsequi profitemur." Fortunately for Mr. Tylor and his fellow-workers, the difficulties which beset the scientific inquirer from this source have probably almost reached their minimum in England. Ecclesiastic thunder itself has lapsed into mere survival, and roars, if it roars at all, only after the fashion of Snug the Joiner's lion.

The remainder of the work, occupying part of the first and the whole of the second volume, is devoted to a discussion of "Animism," in other words, of the philosophy of religion in relation to early and barbaric civilisation. The subject is one of almost equal interest, importance, and difficulty, and Mr. Tylor's treatment of it is eminently original and masterly. Tracing the origin of a belief in spiritual beings to the result of primæval thought on the problems presented by the difference between the dead and the living body, by sleep and waking, trance, disease, and death, he follows the course of its development upwards into the existing religions of the most civilised races. Showing how the doctrine which teaches a possible continued existence after death of the souls of individual creatures really supplied a theory adequate to explain the phenomena to the barbaric intellect, he calls attention to the process by which this belief in a ghost-soul became expanded into a belief in other spirits, who were held to control the events of the material world, and hence became the objects of worship and propitiation, until Animism reached its full development in a system inculcating a belief in controlling deities and subordinate spirits, in souls separable from bodies and a future state of existence, 
morality being incorporated into religion only in the later stages of culture. One of the most striking points in the whole work is Mr. Tylor's identification of the theory of "images" generally ascribed to Democritus with the savage theory of object-souls. Democritus explained the fact of perception by declaring that things are always throwing off images of themselves, which images, assimilating to themselves the surrounding air, enter a recipient soul and are thus perceived. This theory, Mr. Tylor adduces evidence to prove, is merely an application to the phenomena of thought of one of the most characteristic doctrines of savagery, the doctrine that every object, inanimate as well as animate, possesses a soul of its own. "Nor is the correspondence," says Mr. Tylor, "a mere coincidence, for at this point of junction between classic religion and classic philosophy the traces of historic continuity may be still discerned. To say that Democritus was an ancient Greek is to say that from his childhood he had looked on at the funeral ceremonies of his country, beholding the funeral sacrifices of garments and jewels and money and food and drink, rites which his mother and his nurse could tell him were performed in order that the phantasmal images of these objects might pass into the possession of forms shadowy like themselves, the souls of dead men. Thus Democritus, seeking a solution of his great problem of the nature of thought, found it by simply decanting into his metaphysics a surviving doctrine of primitive savage animisn." No more pregnant identification of philosophic tenets with those of earlier religion has been achieved since Comte traced back to fetishism the conception of a soul of the universe as held by certain pantheistic schools.

In describing the nature of the soul as understood by the lower races-well indicated by the way in J. Amos Comenius's "Orbis Sensualium Pictus," where he figures anima hominis as a dotted outline of a man-Mr. Tylor calls special attention to the spirit-voice, which is conceived as a murmur, chirp, or whistle-as it were the ghost of a voice. Among the Algonquins souls chirp like crickets; among the New Zealanders, Polynesians, and Zulus, they squeak or whistle. Nicolaus Remigius, whose "Dæmonolatreia" is one of the ghastliest volumes in the ghastly literature of witchcraft, cites Hermolaus Barbarus as having heard the voice sub-sibilantis diemonis, and, after giving other instances, adduces the authority of Psellus to prove that the devils generally speak very low and confusedly in order not to be caught fibbing. The idea of ghosts whistling is still far from extinct in England. In Leicestershire and elsewhere it is reckoned "very bad" to hear "the Seven Whistlers," though strict inquiry about them only elicits the suggestive fact that "the develin" or common martin-" is one on 'em."

In his account of the doctrine of transmigration of souls, Mr. Tylor forbears to touch on one circumstance, which probably exercised some considerable influence on its development. When two systems of mythology, both originally derived from the same source, came into close contact after long separation, both the difference and the similarity between them could hardly escape attention. If the names of certain deities common to the two systems had been changed while their history and attributes had remained substantially unaltered, the theory of transmigration would, in some cases, satisfactorily account for the phenomenon. In fact, mythologically, the doctrine of transmigration is simply true. Mythology is just now demanding of history the extradition of William Tell, on the plea that his ghost is one which has transmigrated from her domain; and the scientific detective who falls in with Robin Hood or King Arthur will hardly fail to recognise in the one the transmigrated soul of Phobus Apollo, in the other, the wandering spirit of the Bear-ward in Böotes, returned from his long sojourn in the northern sky.

Tempting, however, as are the inquiries suggested in this profusely suggestive work, the reviewer's limit has already been transgressed. We have not yet, we cannot have for years, or for ages, anything approaching to a complete science of history or exhaustive philosophy of religion, but the scientific student of Primitive Culture will at least admit that in these volumes the foundation of both has been "well and truly laid."

\section{BOOK SHELF}

\section{Dr. Dobell's Reports on the Progress of Practical Medicine} in different Parts of the World. Vol, ii. (1871, Longmans.)

IN these reports Dr. Dobell aims at obtaining from the natives of different countries concise statements of the advances made in medicine and the allied branches of knowledge, which have appeared in foreign journals, or in a more permanent form. He has obtained more or less full and detailed reports from America, Australia, California, China, France, Germany, Iceland, India, Italy, Java, Newfoundland, New Zealand, Portugal, Prince Edward's Island, Shetland Isles, Turkey, and the United Kingdom. The idea is a good one. The flood of periodical literature is so great that it is most difficult to keep up with the weekly journals of this country alone, and it becomes almost hopeless to do so with those of France and Germany. Such reports as those before us materially lighten labour, and the only objection to them is that a man who is working at any given subject cannot rely upon their being complete. The report on French progress by Prof. Villemin is a good one. That on German advances, by Dr. Alhaus is much too short. It might, with great advantage, have been extended at the expense of the excerpts from English writers. Everyone has access to the leading English journals, and, moreover, this part of the work is already well done by Braithwaite and Ranking, but comparatively few have access to Virchow's Archiv, the Deutsch Klinilk, and the Wiener Medizinische Zeitung. Many of the English abstracts might have been condensed. We miss a Russian report. Yet both Russian naturalists and Russian physicians have journals of their own. On the whole the book is a useful one, and we can recommend it to our readers as containing a considerable mass of information which they will not elsewhere easily find.

Geometrische Seh-Proben zur Bestimmung der Sehschärfe bei Functions-priifungen des Auges. Von Dr. Boettcher. (Berlin, I870. London: Williams and Norgate).

THIs little book, with its test objects, is intended as a substitute for Snellen's test types to be used by those who are unable to read, and has been drawn up by Dr. Boettcher, with especial reference to the testing of the vision of re.cruits. Besides the ordinary types, it contains a number of figures of squares and rectangles, variously disposed. in regard to one another at different distances, and it need scarcely be added of various sizes. The very smallest require good vision to enumerate their number and disposition at the ordinary distance of eight inches, whilst the largest should be seen at two hundred feet. They afford 